\title{
Isolation and Characterization of Desulfitobacterium dehalogenans gen. nov., sp. nov., an Anaerobic Bacterium Which Reductively Dechlorinates Chlorophenolic Compounds
}

\author{
ILYA UTKIN, ${ }^{1}$ CARL WOESE, ${ }^{2}$ AND JUERGEN WIEGEL ${ }^{1 *}$ \\ Department of Microbiology and Center for Biological Resource Recovery, University of Georgia, Athens, Georgia \\ $30602,{ }^{1}$ and Department of Microbiology, University of Illinois at Urbana-Champaign, Urbana, Illinois $61801^{2}$
}

\begin{abstract}
An organism that is able to reductively ortho-dechlorinate 2,4-dichlorophenol and 3-chloro-4-hydroxyphenylacetate (3-Cl-4-OHPA) was isolated from a methanogenic lake sediment. This organism, an anaerobic, motile, Gram-type-positive, rod-shaped bacterium, grew in the presence of $0.1 \%$ yeast extract when pyruvate, lactate, formate, or hydrogen was used as the electron donor for reductive dehalogenation of 3-Cl-4-OHPA. Sulfite, thiosulfate, and sulfur were reduced to sulfide, nitrate was reduced to nitrite, and fumarate was reduced to succinate. Dissimilatory reduction of sulfate could not be demonstrated, and no adenylylsulfate reductase was detected with an immunoassay. The organism fermented two pyruvate molecules to one lactate molecule, one acetate molecule, and one carbon dioxide molecule. The $\mathrm{pH}$ and temperature optima for both growth and dechlorination of 3-Cl-4-OHPA were 7.5 and $38^{\circ} \mathrm{C}$, respectively. The doubling time under these conditions was approximately $3.5 \mathrm{~h}$. On the basis of the results of a 16S rRNA analysis and the inability of the organism to use sulfate as an electron acceptor, strain JW/IU-DC1 is described as the type strain of the new taxon Desulfitobacterium dehalogenans gen. nov., sp. nov.
\end{abstract}

Although there have been many reports of reductive dehalogenation of chloroaromatic compounds in sediments and enrichment cultures (25), only two obligate anaerobes have been isolated in pure culture, the Gram-type-negative sulfatereducing bacterium Desulfomonile tiedjei DCB-1 $(10,28)$ and a clostridium-like strain, DCB-2 (22).

In this paper we describe the isolation and characterization of an anaerobic Gram-type-positive organism, Desulfitobacterium dehalogenans gen. nov., sp. nov., that is capable of reductive ortho-dechlorination of chloroaromatic compounds such as 2,4-dichlorophenol (2,4-DCP) and 3-chloro-4-hydroxyphenylacetate (3-Cl-4-OHPA).

\section{MATERIALS AND METHODS}

Origin of enrichment culture and organism. The enrichment culture used in this study was obtained from a freshwater sediment collected from a pond located in a wooded area of the Sandy Creek Nature Park, Athens, Ga. (7, 19). Desulfitobacterium dehalogenans JW/IU-DC1 ${ }^{\mathrm{T}}(\mathrm{T}=$ type strain) was isolated from the enrichment culture as described below.

Enrichment, isolation, and cultivation of the dechlorinating organism. Using oxygen-free nitrogen gas, we prepared media by the Hungate technique (21) and sterilized media by autoclaving them at $121^{\circ} \mathrm{C}$ for $40 \mathrm{~min}$. Unless indicated otherwise, cultures were grown anaerobically at $37^{\circ} \mathrm{C}$ in Hungate tubes (borosilicate glass; 16 by $125 \mathrm{~mm}$; Belco Glass, Inc., Vineland, N.J.) containing 5 to $10 \mathrm{ml}$ of medium.

The enrichment culture was grown in a mineral medium described previously (39), except that our medium contained 2 $\mathrm{mM} \mathrm{KH} \mathrm{KO}_{4}$ and $40 \mathrm{mM} \mathrm{N}$-tris(hydroxymethyl)methyl-3aminopropanesulfonic acid (TAPS). Unless indicated otherwise below, the enrichment medium was supplemented with yeast extract $(0.2$ to $1 \%)$ as a carbon source. The $\mathrm{pH}$ was kept

${ }^{*}$ Corresponding author. Mailing address: Department of Microbiology, 215 Biological Sciences Building, University of Georgia, Athens, GA 30602-2605. Phone: (706) 542-2651. Fax: 542-2674. Electronic mail address: jwiegel@uga.cc.uga.edu. within the range from 8.0 to 8.4 by adjusting it with anaerobic sterile $2 \mathrm{~N} \mathrm{NaOH}$. The medium used for further enrichment and isolation was prepared by using the spent medium from a coculture of Clostridium sp. strain JW/IU-YU1 and a facultative anaerobic coccus (JW/IU-DC1), both of which were isolated previously from the primary stable enrichment culture. The spent medium was obtained by growing the coculture in the mineral medium described above supplemented with 0.5 or $0.1 \%$ yeast extract and $0.1 \%(\mathrm{wt} / \mathrm{vol})$ glucose. After centrifugation of the cultures (which were kept in Hungate tubes), transfer of the supernatant into new sterile, anaerobic tubes, autoclaving for $40 \mathrm{~min}$ at $121^{\circ} \mathrm{C}$, and adjustment of the $\mathrm{pH}$ to 8.2 with anaerobic, sterile $2 \mathrm{~N} \mathrm{NaOH}$, the supernatant was supplemented with $15 \mathrm{mM}$ 3-Cl-4-OHPA. Final isolation was accomplished by repeatedly isolating single colonies growing in agar $(0.6$ and $0.9 \%$, wt/vol) shake cultures, using the enrichment medium described above supplemented with $2 \mathrm{mM}$ pyruvate, $2 \mathrm{mM}$ formate, and $1 \mathrm{mM}$ 3-Cl-4-OHPA. The mineral medium (base medium) used for cultivation of the purified culture was the same as the enrichment medium (see above) except that it contained $40 \mathrm{mM} \mathrm{KH}_{2} \mathrm{PO}_{4}$ and no TAPS. The $\mathrm{pH}$ was adjusted to 7.5 with anaerobic sterile $2 \mathrm{~N} \mathrm{NaOH}$ after the medium was autoclaved at $121^{\circ} \mathrm{C}$ for $40 \mathrm{~min}$. Unless indicated otherwise, the medium was supplemented with $0.1 \%$ yeast extract, $20 \mathrm{mM}$ pyruvate, and $10 \mathrm{mM} \mathrm{3-Cl-4-OHPA}$ (purified-culture medium).

Light microscopy and electron microscopy. Phase-contrast light microscopy (model PM-10AD; Olympus Optical Co., Ltd., Tokyo, Japan) was used for routine examinations and for taking photomicrographs of agar-coated slides. Electron microscopy and preparation of cells for ultrathin sectioning were carried out as described previously $(13,17,29)$ by using uranyl acetate and lead citrate for poststaining. Cells were negatively stained as described by Valentine et al. (30) and Beuscher et al. (3) by using $2 \%$ uranyl acetate.

Gram stain reaction and Gram type. Gram staining was performed by a modified Hucker method (12), using an Enhanced Gram Stain Kit (Carr Scarborough Microbiologicals, Inc., Decatur, Ga.). The Gram type (34) was determined 
by the polymyxin B-lipopolysaccharide assay as described previously (36).

Substrate utilization and electron donors for dehalogenation. Tubes containing the base medium described above were supplemented with $0.1 \%$ yeast extract and filter-sterilized substrates at final concentrations of $0.2 \%$ (wt/vol) for the sugars and $20 \mathrm{mM}$ for all of the other organic substrates. Control tubes contained no added carbon source. Cultures grown on $20 \mathrm{mM}$ pyruvate at $37^{\circ} \mathrm{C}$ and $\mathrm{pH} 7.5$ were used as inocula $(2 \% \mathrm{vol} / \mathrm{vol})$. The use of potential electron donors for reductive dehalogenation was assayed in cultures containing 10 mM 3-Cl-4-OHPA. Tubes containing hydrogen as the electron donor were incubated with shaking at $150 \mathrm{rpm}$ (New Brunswick Scientific Co., Inc., Edison, N.J.). A culture grown on medium containing $20 \mathrm{mM}$ pyruvate plus $10 \mathrm{mM} 3-\mathrm{Cl}-4-$ OHPA was used as the inoculum. Growth was monitored by determining the increase in optical density at $600 \mathrm{~nm}$ at $37^{\circ} \mathrm{C}$ and $\mathrm{pH} 7.5$. Assays for reductive dechlorination (see below) were performed in duplicate. The maximum incubation time was 11 days.

Electron acceptors. The use of different electron acceptors was studied with cultures grown in base medium supplemented with $0.1 \%$ yeast extract and various test compounds, using 20 $\mathrm{mM}$ pyruvate as the carbon source at $37^{\circ} \mathrm{C}$ and $\mathrm{pH} 7.5$. All assays were carried out in duplicate. Two uninoculated tubes were used as controls. Chlorophenolic compounds and products of the reduction of these compounds were quantified by high-performance liquid chromatography (HPLC) (Rabbit HP System; Rainin Instrument Co.), using a $\mathrm{C}_{18}$ reversed-phase column as described by Kohring et al. (19). The test for dissimilatory reduction of nitrate $(5 \mathrm{mM})$ and fumarate $(10$ $\mathrm{mM}$ ) was performed in Hungate tubes containing purifiedculture medium. Concentrations of nitrate and nitrite were measured spectrophotometrically as described by Hanson and Philips (14). Fumarate and succinate were quantified by gas chromatography, using a model 5880A instrument (HewlettPackard, Avondale, Pa.) and a Chromosorb WAW 10\% SP1000 glass column (Supelco, Inc., Bellefonte, Pa.), and were measured with a flame ionization detector as described previously (35). Purified-culture medium lacking $\mathrm{Na}_{2} \mathrm{~S}$ and supplemented with $0.1 \% \mathrm{FeSO}_{4}$ was used to assay for dissimilatory reduction of sulfate, sulfite, thiosulfate, and sulfur. Tubes were supplemented with 5 and $10 \mathrm{mM} \mathrm{Na}_{2} \mathrm{SO}_{4}, 2 \mathrm{mM} \mathrm{Na}_{2} \mathrm{SO}_{3}, 5$ and $20 \mathrm{mM} \mathrm{Na}_{2} \mathrm{~S}_{2} \mathrm{O}_{3}$, and sulfur powder (about $0.2 \%$ added with a spatula in an anaerobic chamber). All tubes were pressurized with hydrogen $\left(20 \mathrm{lb} / \mathrm{in}^{2}\right)$. Adenylylsulfate reductase was detected with an immunoassay test kit for the detection of sulfate-reducing bacteria (Conoco Specialty Products, Houston, Tex.).

pH and temperature ranges. The $\mathrm{pH}$ and temperature ranges for growth and dechlorination were determined by growing the dechlorinating organism in Hungate tubes containing $10 \mathrm{ml}$ of purified-culture medium. The medium used to determine the $\mathrm{pH}$ range contained $25 \mathrm{mM}$ potassium phosphate and $25 \mathrm{mM}$ TAPS as buffers rather than $40 \mathrm{mM}$ potassium phosphate. The $\mathrm{pH}$ was kept constant by frequently adjusting it with sterile anaerobic $2 \mathrm{~N} \mathrm{NaOH}$. The $\mathrm{pH}$ range was determined at $37^{\circ} \mathrm{C}$. The temperature range was determined at $\mathrm{pH} 7.5$ by using a temperature gradient incubator (Scientific Industries, Inc., Bohemia, N.Y.) set at temperatures ranging from 1.6 to $53^{\circ} \mathrm{C}$ with a shaking speed of $15 \mathrm{spm}$.

Sporulation. To induce spore formation, Desulfitobacterium dehalogenans was grown under various conditions, including in liquid or agar $(0.6 \%$, wt $/ \mathrm{vol})$-solidified purified-culture medium. In a coculture with Clostridium sp. strain JW/IU-YU1 and facultatively anaerobic coccus strain JW/IU-YU2,
Desulfitobacterium dehalogenans was grown in $0.5 \%$ yeast extract medium supplemented with $0.4 \mathrm{mM} \mathrm{2,4-DCP}$ at $37^{\circ} \mathrm{C}$ and $\mathrm{pH}$ 8.0. Cultures were analyzed for spore formation by phase-contrast light microscopy and by testing for heat resistance (i.e., growth after treatment at $87^{\circ} \mathrm{C}$ for $30 \mathrm{~min}$ ).

Fermentation products. $\mathrm{H}_{2}$ and $\mathrm{CO}_{2}$ were determined by gas chromatography (Varian, Walnut Creek, Calif., instrument equipped with a Porapak Q 80/100-mesh column [Supelco] and a thermal conductivity detector). The temperatures of the injection port and the column were 160 and $120^{\circ} \mathrm{C}$, respectively. The carrier gas was nitrogen, and the flow rate was 30 $\mathrm{ml} / \mathrm{min}$. Volatile fatty acids and alcohols, as well as nonvolatile fatty acids, were analyzed as described previously (35) by using a model 5880A gas chromatograph (Hewlett-Packard) equipped with a Chromosorb WAW 10\% SP-1000 glass column (Supelco) and a flame ionization detector. Formic acid contents were determined by monitoring NAD reduction at $340 \mathrm{~nm}$ in the presence of NAD-dependent formate dehydrogenase obtained from yeast cells (Boehringer Mannheim GmbH, Mannheim, Germany). Acetic acid contents were determined enzymatically by using an acetic acid reagent kit (catalog no. 148-261; Boehringer Mannheim GmbH).

Determination of $\mathbf{G}+\mathbf{C}$ content. DNA was isolated as described by Ausubel et al. (2) by using $\mathrm{CsCl}$ gradient ultracentrifugation. The guanine-plus-cytosine $(\mathrm{G}+\mathrm{C})$ content was determined after enzymatic digestion and HPLC separation of nucleosides as described by Whitman et al. (32) and Mesbah et al. (24).

16S rRNA isolation, sequencing method, and data analysis. $16 \mathrm{~S}$ rRNA was isolated from strain $\mathrm{JW} / \mathrm{IU}-\mathrm{DC} 1^{\mathrm{T}}$ by previously described procedures $(23,38)$. The dideoxynucleotide chain termination method $(4,27)$, adapted for direct rRNA sequencing using reverse transcriptase (20), was employed. Synthesized strands were labeled by including $\left[\alpha^{-35}\right.$ S $]$ thio-dATP (4). A standard set of primers (usually eight) specific for (eu)bacterial $16 \mathrm{~S}$ rRNAs $(4,20,31)$ was routinely used. All sequences were $>90 \%$ complete. The sequences were aligned by using sequence editor ae2 (C. R. Woese) with the sequences of a representative collection of (eu)bacterial $16 \mathrm{~S}$ rRNAs $(26,37)$. Corrected pairwise distances (expressed as estimated numbers of changes per 100 nucleotides) were computed from percentages of similarity by using the Jukes-Cantor correction (16) as modified by G. J. Olsen (described in reference 31 ) to accomodate the actual nucleotide ratios. Dendograms were constructed from evolutionary distance matrices by using the algorithm of De Soete (9).

Sensitivity to oxygen. Sensitivity of bacterial growth and dechlorination of 3-Cl-4-OHPA to oxygen was determined in $160-\mathrm{ml}$ serum bottles containing $10 \mathrm{ml}$ of purified-culture medium (which contained no reducing solution) under a nitrogen atmosphere in the presence of $0,0.5,1,2,5$, and $9 \%$ air. The medium in each tube was inoculated with $0.25 \mathrm{ml}$ of a culture of strain JW/IU-DC1 ${ }^{\mathrm{T}}$ in the exponential growth phase. The bottles were incubated in a shaking incubator (New Brunswick Scientific Co.) at $37^{\circ} \mathrm{C}$ and $150 \mathrm{rpm}$. The maximum incubation time was 15 days.

Effect of sodium chloride on growth and dechlorination. Sensitivity of growth and dechlorination to $\mathrm{NaCl}$ was tested by transferring portions $(2 \%, \mathrm{vol} / \mathrm{vol})$ of an exponentially growing culture into fresh purified-culture medium containing $0,0.5,1$, $1.5,2$, and $2.5 \mathrm{M} \mathrm{NaCl}$.

Nucleotide sequence accession number. The GenBank accession number for the 16S rRNA sequence of strain JW/IU$\mathrm{DC}^{\mathrm{T}}{ }^{\mathrm{T}}$ is $\mathrm{L} 28946$. 
TABLE 1. Evolutionary distances between Desulfitobacterium dehalogenans and related organisms ${ }^{a}$

\begin{tabular}{|c|c|c|c|c|c|c|c|c|c|c|c|c|c|c|c|c|c|c|c|c|c|c|c|c|}
\hline \multirow[b]{2}{*}{ Organism } & \multicolumn{24}{|c|}{ Evolutionary distance } \\
\hline & 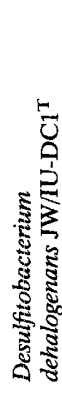 & 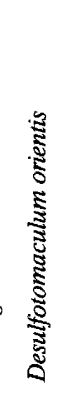 & 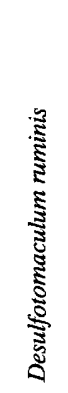 & 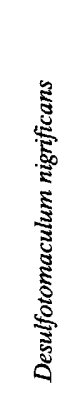 & 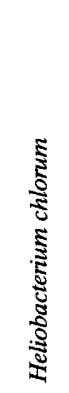 & 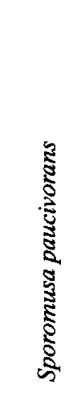 & 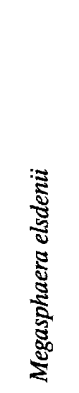 & 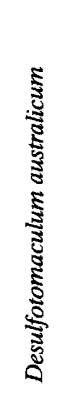 & 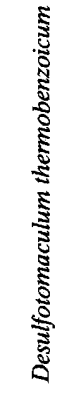 & 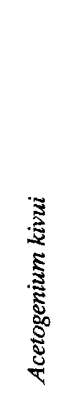 & 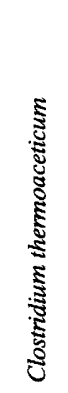 & 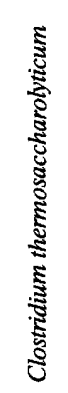 & 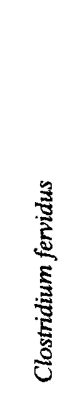 & 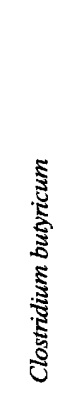 & 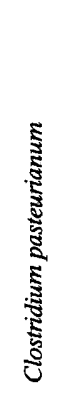 & 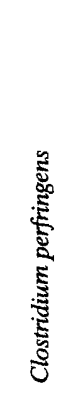 & 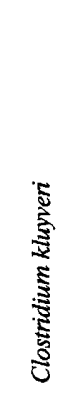 & 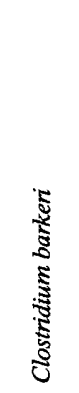 & 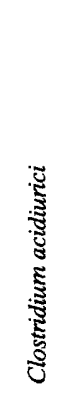 & 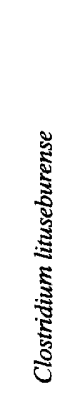 & 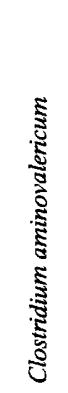 & 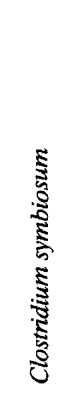 & 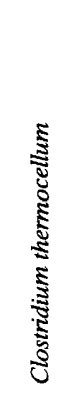 & 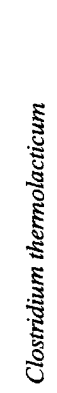 \\
\hline $\begin{array}{l}\text { Desulfotomaculum } \\
\text { orientis }\end{array}$ & 9.2 & & & & & & & & & & & & & & & & & & & & & & & \\
\hline $\begin{array}{l}\text { Desulfotomaculum } \\
\text { ruminis }\end{array}$ & 14.6 & 16.9 & & & & & & & & & & & & & & & & & & & & & & \\
\hline $\begin{array}{l}\text { Desulfotomaculum } \\
\text { nigrificans }\end{array}$ & 15.0 & 17.4 & 7.8 & & & & & & & & & & & & & & & & & & & & & \\
\hline $\begin{array}{l}\text { Heliobacterium } \\
\text { chlorum }\end{array}$ & 14.7 & 16.9 & 16.1 & 15.7 & & & & & & & & & & & & & & & & & & & & \\
\hline $\begin{array}{l}\text { Sporomusa } \\
\text { paucivorans }\end{array}$ & 19.0 & 18.1 & 21.9 & 19.9 & 20.5 & & & & & & & & & & & & & & & & & & & \\
\hline $\begin{array}{l}\text { Megasphaera } \\
\text { elsdenii }\end{array}$ & 18.6 & 19.2 & 20.7 & 18.9 & 22.5 & 515.5 & & & & & & & & & & & & & & & & & & \\
\hline $\begin{array}{l}\text { Desulfotomaculum } \\
\text { australicum }\end{array}$ & 15.4 & 16.1 & 14.5 & 13.6 & 17.3 & 321.2 & 21.1 & & & & & & & & & & & & & & & & & \\
\hline $\begin{array}{l}\text { Desulfotomaculum } \\
\text { thermobenzoicum }\end{array}$ & 14.8 & 16.4 & 14.1 & 12.3 & 17.2 & 219.6 & 20.4 & 4.7 & & & & & & & & & & & & & & & & \\
\hline Acetogenium kivui & 17.7 & 18.0 & 18.4 & 17.4 & 18.2 & 20.3 & 20.3 & 12.2 & 12.2 & & & & & & & & & & & & & & & \\
\hline $\begin{array}{l}\text { Clostridium } \\
\text { thermoaceticum }\end{array}$ & 15.4 & 16.4 & 16.4 & 14.3 & 17.4 & +19.0 & 18.4 & 11.2 & 10.6 & 10.8 & & & & & & & & & & & & & & \\
\hline $\begin{array}{l}\text { Clostridium } \\
\text { thermosaccharo- } \\
\text { lyticum }\end{array}$ & 20.8 & 21.6 & 19.0 & 18.2 & 19.7 & 23.6 & 19.5 & 15.9 & 15.5 & 12.8 & 12.8 & & & & & & & & & & & & & \\
\hline $\begin{array}{l}\text { Clostridium } \\
\text { fervidus }\end{array}$ & 18.2 & 19.5 & 19.2 & 18.0 & 17.3 & 22.4 & 21.5 & 16.8 & 16.0 & 14.6 & 14.3 & 15.5 & & & & & & & & & & & & \\
\hline $\begin{array}{l}\text { Clostridium } \\
\text { butyricum }\end{array}$ & 20.1 & 21.1 & 20.9 & 19.7 & 20.8 & 23.6 & 25.2 & 21.8 & 21.4 & 21.6 & 18.8 & 19.4 & 15.4 & & & & & & & & & & & \\
\hline $\begin{array}{l}\text { Clostridium } \\
\text { pasteurianum }\end{array}$ & 21.2 & 20.4 & 22.1 & 20.7 & 19.6 & 22.3 & 24.6 & 22.2 & 22.9 & 20.8 & 18.2 & 19.8 & 14.7 & 6.9 & & & & & & & & & & \\
\hline $\begin{array}{l}\text { Clostridium } \\
\text { perfringens }\end{array}$ & 18.9 & 18.6 & 21.5 & 20.5 & 19.7 & 25.2 & 25.2 & 20.3 & 20.8 & 19.6 & 18.9 & 18.2 & 15.4 & 6.5 & 8.6 & & & & & & & & & \\
\hline $\begin{array}{l}\text { Clostridium } \\
\text { kluyveri }\end{array}$ & 21.5 & 21.1 & 20.3 & 21.1 & 20.4 & 23.8 & 24.9 & 21.8 & 20.7 & 20.4 & 18.0 & 17.7 & 15.0 & 11.2 & 9.2 & 10.9 & & & & & & & & \\
\hline $\begin{array}{c}\text { Clostridium } \\
\text { barkeri }\end{array}$ & 21.8 & 20.4 & 20.8 & 21.5 & 23.3 & 24.5 & 25.1 & 20.7 & 20.1 & 21.5 & 18.9 & 19.2 & 21.4 & 19.8 & 19.0 & 18.2 & 17.0 & & & & & & & \\
\hline $\begin{array}{l}\text { Clostridium } \\
\text { acidiurici }\end{array}$ & 18.2 & 20.4 & 19.2 & 18.6 & 20.8 & 24.6 & 24.8 & 18.1 & 18.0 & 19.0 & 15.7 & 17.7 & 16.9 & 14.6 & 15.4 & 15.1 & 15.6 & 14.0 & & & & & & \\
\hline $\begin{array}{l}\text { Clostridium } \\
\quad \text { lituseburense }\end{array}$ & 18.6 & 20.8 & 19.3 & 19.3 & 20.9 & 24.5 & 23.2 & 19.0 & 19.6 & 19.2 & 16.6 & 19.8 & 18.1 & 15.0 & 16.5 & 14.7 & 17.6 & 18.5 & 13.3 & & & & & \\
\hline $\begin{array}{l}\text { Clostridium } \\
\text { aminovalericum }\end{array}$ & 18.4 & 20.4 & 19.4 & 18.5 & 21.6 & 22.6 & 21.9 & 21.2 & 20.1 & 20.3 & 18.1 & 21.0 & 16.1 & 16.4 & 16.8 & 17.3 & 18.2 & 20.4 & 15.5 & 15.7 & & & & \\
\hline $\begin{array}{l}\text { Clostridium } \\
\text { symbiosum }\end{array}$ & 20.8 & 21.8 & 22.2 & 21.2 & 20.8 & 23.8 & 22.5 & 22.4 & 21.9 & 21.7 & 19.9 & 22.2 & 20.3 & 18.0 & 19.0 & 17.3 & 20.5 & 22.3 & 18.9 & 16.3 & 9.2 & & & \\
\hline $\begin{array}{l}\text { Clostridium } \\
\text { thermocellum }\end{array}$ & 17.0 & 17.8 & 18.8 & 17.3 & 18.8 & 19.7 & 18.5 & 17.2 & 16.3 & 17.0 & 15.0 & 16.8 & 14.5 & 16.5 & 17.4 & 16.4 & 17.4 & 17.2 & 17.3 & 17.6 & 15.5 & 18.4 & & \\
\hline $\begin{array}{l}\text { Clostridium } \\
\text { thermolacticum }\end{array}$ & 18.0 & 18.6 & 19.5 & 19.0 & 19.5 & 21.2 & 18.8 & 17.7 & 16.7 & 16.9 & 15.5 & 18.1 & 15.0 & 20.5 & 20.4 & 20.5 & 19.2 & 19.7 & 18.5 & 19.9 & 14.8 & 17.3 & 7.8 & \\
\hline Bacillus subtilis & 16.1 & 16.4 & 18.5 & 17.4 & 19.4 & 19.7 & 22.8 & 17.6 & 16.1 & 18.2 & 15.1 & 18.9 & 17.4 & 18.1 & 17.8 & 17.6 & 18.4 & 18.1 & 16.8 & 18.4 & 19.8 & 20.5 & 19.4 & 22.1 \\
\hline
\end{tabular}

${ }^{a}$ Only those positions having known bases in all sequences were used in the analysis. Bacillus subtilis was used as an unweighted outgroup.

\section{RESULTS AND DISCUSSION}

Isolation of dechlorinating strain JW/IU-DC1 ${ }^{\mathrm{T}}$. The starting enrichment culture (7) grown in the presence of $1 \%(\mathrm{wt} / \mathrm{vol})$ yeast extract contained approximately $10^{6}$ to $10^{7}$ dehalogenat- ing cells per $\mathrm{ml}$ of culture, as determined by serial dilution (1:5). Changing the chlorinating compound from $1 \mathrm{mM} \mathrm{2,4-}$ DCP (higher concentrations were inhibitory) to $15 \mathrm{mM} \mathrm{3-Cl-}$ 4-OHPA and using spent medium from a coculture of the yeast extract-utilizing organism Clostridium sp. strain JW/IU-YU1 


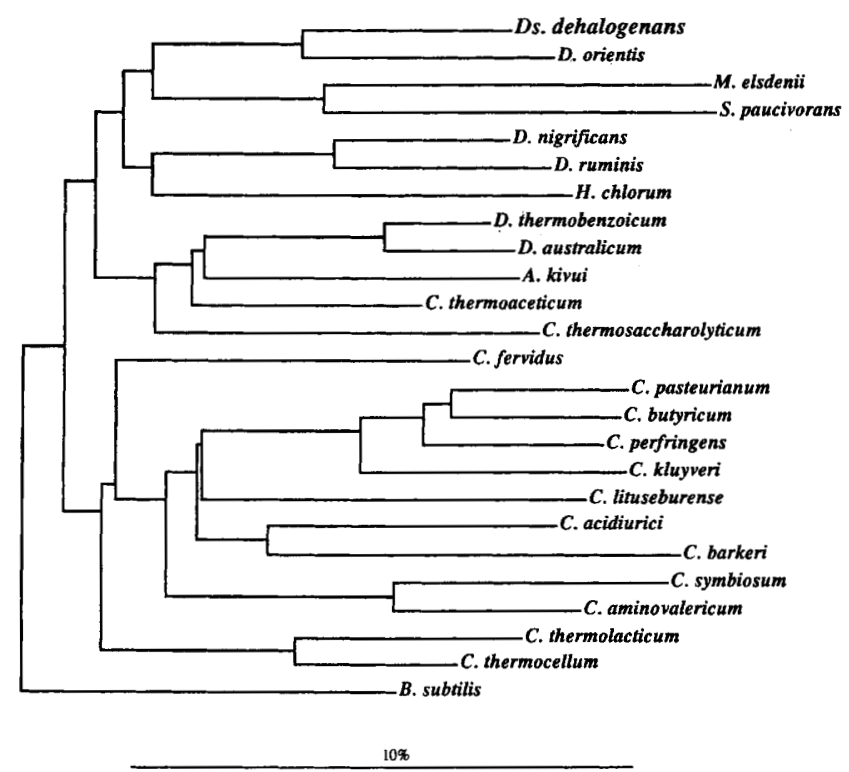

FIG. 1. Unrooted phylogenetic tree for Desulfitobacterium dehalogenans JW/IU-DC1 ${ }^{\mathrm{T}}$ and related organisms based on 16S rRNA sequences (see Materials and Methods and Table 1). Bar $=10$ inferred changes per 100 nucleotides. Abbreviations: A., Acetogenium; B., Bacillus; C., Clostridium; D., Desulfotomaculum; Ds. Desulfitobacterium; H., Heliobacterium; M., Megasphaera; S., Sporomusa. Bacillus subtilis was used as an arbitrary outgroup organism.

and a facultatively anaerobic coccus (JW/IU-YU2), both of which were isolated from the enrichment culture, increased the concentration of the dechlorinating organisms approximately 100 -fold. The culture consisted mainly of two different organisms. A pure culture of the dechlorinating organism was finally obtained by isolating single colonies in soft agar shake cultures containing 0.6 and $0.9 \%$ (wt/vol) agar (21). Higher agar concentrations were inhibitory for the dechlorinating culture but not for the contaminating organism, an unidentified clostridium-like organism. A convenient routine check for the purity of this culture was the lack of growth on and in $1.2 \%$ (wt/vol) agar-solidified medium containing $20 \mathrm{mM}$ pyruvate and $0.3 \%$ yeast extract, a medium that many organisms grow well on.

Phylogeny. The 16S rRNA analysis of strain JW/IU-DC1 ${ }^{T}$ placed it in the Desulfotomaculum-Clostridium subphylum (Table 1; Fig. 1). Desulfotomaculum orientis is the most closely related species (phylogenetic distance, 9.2\%). The new isolate is clearly separated from all groups of Clostridium species for which sequences are currently available, including the species regarded as Clostridium sensu stricto, closely related to the type species, Clostridium butyricum. Like the members of the genus Clostridium, the currently known species that are assigned to the genus Desulfotomaculum do not form a uniform and defined group around the type species, Desulfotomaculum nigrificans. We expect that in the near future both of these genera will be subdivided into different genera. In particular, Desulfotomaculum orientis is about $17 \%$ different from the type species, Desulfotomaculum nigrificans, and thus should belong to a different genus. Additional data (i.e., additional sequences of similar organisms) will be required to decide whether Desulfitobacterium dehalogenans and Desulfotomaculum orientis belong to the same genus. Many phenotypic properties of Desulfitobacterium dehalogenans (see below) and the species belonging to the genus Desulfotomaculum are similar (Table 2). However, on the basis of the results of the 16S rRNA analysis and the inability of the organism to carry out dissimilatory sulfate reduction but using a variety of electron acceptors, including elemental sulfur, we concluded that the strain which we isolated does not belong to any previously validly published genus and placed it, therefore, in a new genus and species, Desulfitobacterium dehalogenans.

Description of the genus Desulfitobacterium gen. nov. Desulfitobacterium (De.sul.fi.to.bac.te'ri.um. L. pref. de, from, off, away; L. n. sulfur, the element sulfur; L. n. sulfite, alteration of sulfate, referring to a less oxygenated sulfur anion; L. masc. n. bacter, rod; Desulfitobacterium, rod-shaped organism that reduces sulfite). The description of this genus is the same as that of Desulfitobacterium dehalogenans, the type and so far only species in the genus.

Description of Desulfitobacterium dehalogenans sp. nov. Desulfitobacterium dehalogenans (de.ha.lo'ge.nans. L. pref. de, off, away; Gr. n. hals, salt, sea; F. n. halogen, referring to the group VII elements; L. pres. part. dehalogenans, dehalogenating, split off halogens, referring to the characteristic property

TABLE 2. Selected properties of Desulfitobacterium dehalogenans and Desulfotomaculum species ${ }^{a}$

\begin{tabular}{|c|c|c|c|c|c|c|c|c|c|}
\hline \multirow{2}{*}{ Species } & \multirow{2}{*}{ Cell morphology } & \multirow{2}{*}{$\begin{array}{l}\text { Morphology and } \\
\text { location of } \\
\text { spores }\end{array}$} & \multirow{2}{*}{$\begin{array}{l}\text { Growth with } \\
\text { pyruvate without } \\
\text { electron acceptors }\end{array}$} & \multirow{2}{*}{$\begin{array}{l}\text { Autotrophic } \\
\text { growth }\end{array}$} & \multicolumn{3}{|c|}{ Electron acceptors } & \multirow{2}{*}{$\begin{array}{c}\mathrm{G}+\mathrm{C} \text { content } \\
\text { of DNA } \\
(\mathrm{mol} \%)\end{array}$} & \multirow{2}{*}{$\begin{array}{c}\text { Oxidation of } \\
\text { organic substrates }\end{array}$} \\
\hline & & & & & Sulfate & Nitrate & Sulfur & & \\
\hline $\begin{array}{c}\text { Desulfitobacterium } \\
\text { dehalogenans }\end{array}$ & $\begin{array}{l}\text { Straight or curved } \\
\text { rods }\end{array}$ & $\begin{array}{l}\text { Usually not } \\
\text { present }\end{array}$ & + & - & - & + & + & 45 & Incomplete \\
\hline $\begin{array}{l}\text { Desulfotomaculum } \\
\text { orientis }\end{array}$ & $\begin{array}{l}\text { Straight or curved } \\
\text { rods }^{c}\end{array}$ & $\begin{array}{l}\text { Slightly oval, } \\
\text { terminal to } \\
\text { subterminal }\end{array}$ & $-^{d}$ & $+^{e}$ & $+^{d}$ & $-^{d}$ & $\mathcal{-}^{f}$ & $45^{b, c}$ & Incomplete $^{c}$ \\
\hline $\begin{array}{l}\text { Desulfotomaculum } \\
\text { nigrificans }\end{array}$ & $\operatorname{Rods}^{c}$ & $\begin{array}{l}\text { Oval, } \\
\text { central }^{c}\end{array}$ & $+^{d}$ & $+e . g$ & $+^{d}$ & $-d$ & $-f$ & $45^{b, c}$ & Incomplete $^{c}$ \\
\hline $\begin{array}{l}\text { Desulfotomaculum } \\
\text { ruminis }\end{array}$ & $\operatorname{Rods}^{c}$ & $\begin{array}{l}\text { Oval, } \\
\text { central }^{c}\end{array}$ & $+^{d}$ & $t^{e g}$ & $+^{d}$ & $-{ }^{d}$ & $-f$ & $49^{b, c}$ & Incomplete $^{c}$ \\
\hline
\end{tabular}

${ }^{a}$ Desulfitobacterium dehalogenans and the Desulfotomaculum species $(5,18)$ use lactate, pyruvate, $\mathrm{H}_{2}$, and formate but not acetate as electron donors for reduction of 3-Cl-4-OHPA and sulfate, respectively.

${ }^{b}$ The values for Desulfotomaculum species are different from the values in references 5 and 6 .

c Data from reference 33 .

${ }^{d}$ Data from reference 5.

${ }^{e}$ Data from reference 18 .

$f$ Data from reference 15 .

${ }^{g}$ Determined in the presence of $1 \mathrm{mmol}$ of acetate per liter. 


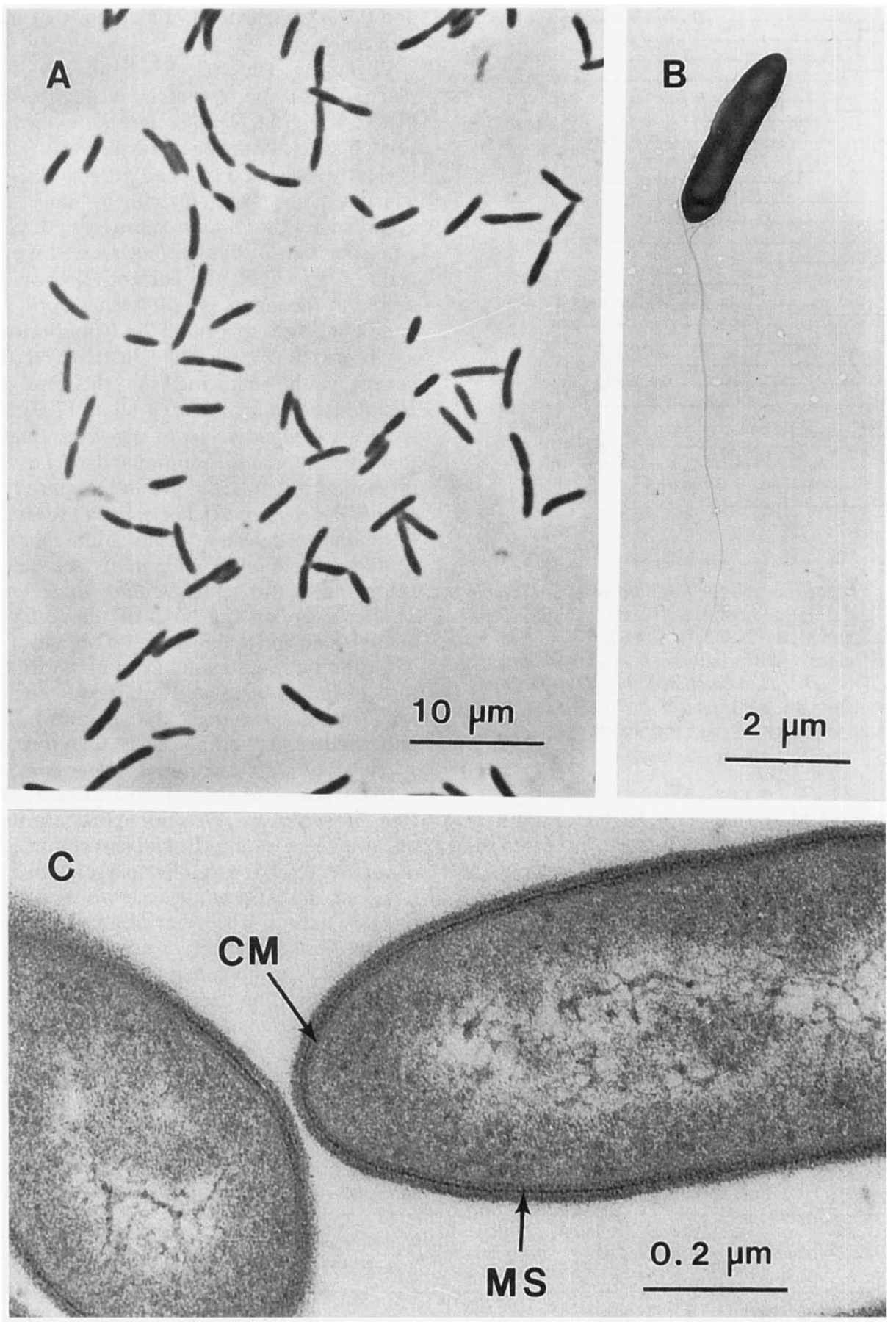

FIG. 2. Phase-contrast light micrograph (A) and electron micrographs of a negatively stained cell (B) and an ultrathin section (CM, cytoplasmic membrane; MS, murein sacculus) (C) of Desulfitobacterium dehalogenans in the middle exponential phase. Desulfitobacterium dehalogenans was grown in purified-culture medium at $37^{\circ} \mathrm{C}$ and $\mathrm{pH} 7.5$.

of the organism to dehalogenate various chlorophenolic compounds).

Colony morphology. The organism does not grow in or on the surfaces of solid 1 to $1.5 \%$ agar media containing $0.1 \%$ yeast extract, $20 \mathrm{mM}$ pyruvate, and 1 to $10 \mathrm{mM} \mathrm{3-Cl-4-OHPA}$. Colonies in 0.7 to $0.8 \%$ agar shake tubes are translucent, white, and spherical to slightly irregular and have diameters of 2 to 3 mm.

Morphology of vegetative cells. Exponential-phase cells that are grown in liquid medium are slightly curved rods that are 0.5 to $0.7 \mu \mathrm{m}$ in diameter and 2.5 to $4 \mu \mathrm{m}$ long (Fig. 2A and B). The cells become more pleiomorphic (i.e., thicker and shorter cells appear) in the early stationary growth phase.

Gram stain reaction and Gram type. The Gram stain reaction is positive, regardless of the growth phase. Furthermore, tests for formation of the lipopolysaccharide-polymyxin $\mathrm{B}$ complex give no indications for the presence of lipopolysaccharide (36). Thus, the organism is a Gram-type-positive (34) 

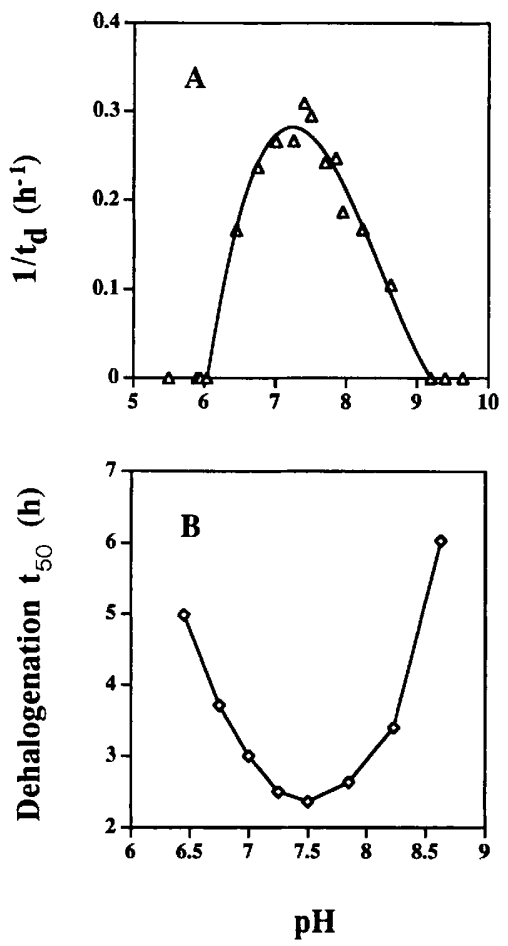

FIG. 3. Effects of $\mathrm{pH}$ on the doubling time $\left(\mathrm{t}_{\mathrm{d}}\right)$ of $\mathrm{JW} / \mathrm{IU}-\mathrm{DC} 1^{\mathrm{T}}$ (A) and the observed time for $50 \%$ dehalogenation $\left(t_{50}\right)$ of $10 \mathrm{mM}$ 3-Cl-4-OHPA (B). Desulfitobacterium dehalogenans was grown at $37^{\circ} \mathrm{C}$ in modified purified-culture medium (See Materials and Methods).

bacterium. This conclusion is supported by the fine structure of the cell wall, as revealed in photomicrographs of ultrathin sections (Fig. 2C), and also by the data from 16S rRNA analysis, which indicate that the organism belongs to the Gram-type-positive Desulfotomaculum-Clostridium subphylum (Fig. 1).

Sporulation. Although heat stability $\left(25 \mathrm{~min}, 85^{\circ} \mathrm{C}\right)$ of the dechlorinating activity in the original sediment-free enrichment culture has been observed repeatedly, no spores were observed with the purified organism grown in liquid or solidified media (see Materials and Methods). Cells in the late stationary growth phase do not survive heat treatment at $87^{\circ} \mathrm{C}$ for $30 \mathrm{~min}$.

Motility and flagellation. Most exponentially growing cells in purified-culture medium are motile, whereas cells in the later growth stages exhibit mainly tumbling motion. Each cell has one to four flagella (Fig. 2B).

Growth properties. (i) Effects of $\mathrm{pH}$ and temperature on growth. The $\mathrm{pH}$ range for growth and dechlorination of 3-Cl-4-OHPA is pH 6 to 9 (as determined at $37^{\circ} \mathrm{C}$ ), and the optimum $\mathrm{pH}$ is 7.5 (Fig. 3). The shortest doubling time is about $3.5 \mathrm{~h}$ at $\mathrm{pH} 7.5$ and $37^{\circ} \mathrm{C}$. A similar $\mathrm{pH}$ profile with an optimum at about $\mathrm{pH} 7.5$ has been observed for dechlorination of 2,4-DCP (data not shown). The temperature range for growth and dechlorination of 3-Cl-4-OHPA is 13 to $45^{\circ} \mathrm{C}$, and the optimum temperature is around $38^{\circ} \mathrm{C}$ (Fig. 4).

(ii) Effect of oxygen. We determined the sensitivity of strain $\mathrm{JW} / \mathrm{IU}-\mathrm{DC} 1^{\mathrm{T}}$ to oxygen by measuring growth and dechlorination of 3-Cl-4-OHPA in 160-ml serum bottles containing $10 \mathrm{ml}$ of medium under a nitrogen gas phase containing different concentrations of air. Growth and dechlorination do not occur under aerobic conditions and when the concentration of air in
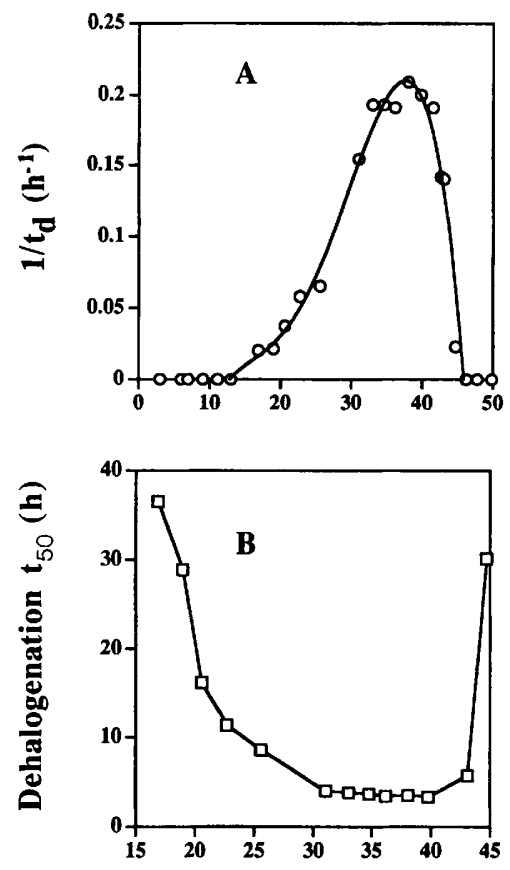

Temperature $\left({ }^{\circ} \mathrm{C}\right)$

FIG. 4. Effects of temperature on the doubling time $\left(t_{d}\right)$ of JW/IU$\mathrm{DC1}^{\mathrm{T}}(\mathrm{A})$ and the observed time for $50 \%$ dehalogenation $\left(t_{50}\right)$ of 10 mM 3-Cl-4-OHPA (B). Desulfitobacterium dehalogenans was grown in purified-culture medium at $\mathrm{pH} 7.5$.

the gas phase is $5 \%$ or more. However, dechlorination does occur under a nitrogen atmosphere containing $2 \%$ air, indicating that the organism is resistant to microaerophilic conditions. Determining whether the organism can use $\mathrm{O}_{2}$ as an electron acceptor will require further research. It has been shown recently that under special conditions some sulfate reducers, which have been assumed to be strictly anaerobic bacteria, not only can survive exposure to air (1) but also can utilize $\mathrm{O}_{2}(8$, 11).

(iii) Effect of sodium chloride. Growth and complete dechlorination of $10 \mathrm{mM} 3-\mathrm{Cl}-4-\mathrm{OHPA}$ occur in the presence of 0.5 $\mathrm{M} \mathrm{NaCl}$, but growth and dechlorination do not occur in the presence of an concentration of $1 \mathrm{M}$ or more. This observation is consistent with the previous observation that the enrichment culture is not active when it is transferred to marine sediments unless the sediment is diluted at least 2:1 with water, thus reducing the salt concentration (7).

(iv) Substrates and fermentation products. The only defined carbon source found which is utilized in the presence of $0.1 \%$ yeast extract under anaerobic conditions is pyruvate. Fermentation of $22.2 \mathrm{~mol}$ of pyruvate results in the formation of 10 mol of lactate, $9.2 \mathrm{~mol}$ of acetate, and $11.2 \mathrm{~mol}$ of carbon dioxide. We conclude that pyruvate is fermented according to the following equation: $2 \mathrm{CH}_{3} \mathrm{COCOOH}+\mathrm{H}_{2} \mathrm{O} \rightarrow$ $\mathrm{CH}_{3} \mathrm{CH}(\mathrm{OH}) \mathrm{COOH}+\mathrm{CH}_{3} \mathrm{COOH}+\mathrm{CO}_{2}$. If the organism is grown on pyruvate in the presence of 3-Cl-4-OHPA or fumarate as an electron acceptor, equimolar amounts of 4-hydroxyphenylacetate and succinate, respectively, are produced instead of lactate. Substrates which do not support growth under anaerobic conditions in the presence of $0.1 \%$ yeast extract include arabinose, cellobiose, galactose, glucose, fructose, lactose, maltose, mannose, mannitol, raffinose, rhamnose, ribose, 


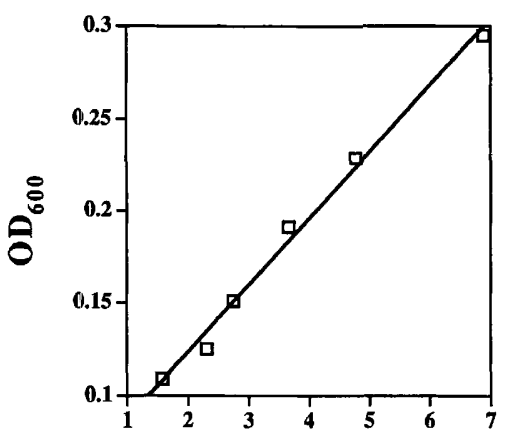

\section{4-OHPA (mM)}

FIG. 5. Correlation between dechlorination of 3-Cl-4-OHPA (measured by the formation of the product 4-hydroxyphenylacetate [4-OHPA]) and growth of JW/IU-DC1 ${ }^{\mathrm{T}}$ (optical density at $600 \mathrm{~nm}$ $\left.\left[\mathrm{OD}_{600}\right]\right)$. Desulfitobacterium dehalogenans was grown in purifiedculture medium at $38^{\circ} \mathrm{C}$ and $\mathrm{pH} 7.5$ by using pyruvate as the major carbon source and 3-Cl-4-OHPA as the major electron acceptor.

sucrose, xylose, lactate, ethanol, methanol, butyrate, i-butyrate, propionate, i-valerate, acetate, and formate.

(v) Electron donors. In the presence of $0.1 \%$ yeast extract and $10 \mathrm{mM} 3-\mathrm{Cl}-4-\mathrm{OHPA}$ as an electron acceptor, pyruvate, lactate, formate, and hydrogen are used as electron donors for reductive dechlorination and, consequently, growth: the doubling times are $3.5,6.2,11.4$, and $15.5 \mathrm{~h}$, respectively. No growth occurs in the absence of 3-Cl-4-OHPA with lactate, formate, and hydrogen. Growth on pyruvate in the absence of 3-Cl-4-OHPA starts after a lag period of more than a day. However, strain JW/IU-DC1 ${ }^{\mathrm{T}}$ cultures grown on $20 \mathrm{mM}$ pyruvate in the presence of $10 \mathrm{mM} 3-\mathrm{Cl}-4-\mathrm{OHPA}$ reach the stationary phase within $24 \mathrm{~h}$. Growth in purified-culture medium is proportional to the amount of 3-Cl-4-OHPA converted to 4-hydroxyphenylacetate (Fig. 5). This indicates that Desulfitobacterium dehalogenans obtains energy through reductive dehalogenation. A thorough investigation to quantify the contribution of dehalogenation to growth yield is under way. The presence of cellobiose, glucose, fructose, mannitol, sucrose, i-butyrate, propionate, i-valerate, or acetate has no measurable beneficial effect on dechlorination or growth.

(vi) Electron acceptors. In addition to chlorophenolic compounds, such as 3-Cl-4-OHPA and 2,4-DCP, the following inorganic and organic compounds are used as electron acceptors in the presence of $0.1 \%$ yeast extract and $20 \mathrm{mM}$ pyruvate: sulfite $(2 \mathrm{mM})$, thiosulfate $(20 \mathrm{mM})$, and sulfur $(5 \%$, wt/vol), which are reduced to sulfide; nitrate $(5 \mathrm{mM})$ (reduced to nitrite); and fumarate (10 $\mathrm{mM})$ (reduced to succinate). The test for dissimilatory sulfate reduction, however, is negative. Moreover, no adenylylsulfate reductase is detected by an immunoassay (see Materials and Methods), thus excluding the possibility that the organism is a sulfate-reducing bacterium. Besides 3-Cl-4-OHPA, cultures of JW/IU-DC1 ${ }^{\mathrm{T}}$ grown in purified-culture medium reductively ortho-dechlorinate a variety of chlorophenols, including the dichlorophenols 2,3-dichlorophenol, 2,4-dichlorophenol, and 2,6-dichlorophenol, the trichlorophenols 2,3,4-trichlorophenol, 2,3,6-trichlorophenol, and 2,4,6-trichlorophenol, the tetrachlorophenols 2,3,4,6-tetrachlorophenol, 2,3,4,5-tetrachlorophenol, and 2,3,5,6-tetrachlorophenol, and pentachlorophenol. The following chlorophenols are not dehalogenated: 2-chlorophenol, 3-chlorophenol, 4-chlorophenol, 2,5-dichlorophenol, 3,4-dichlorophenol, 3,5dichlorophenol, and 3,4,5-trichlorophenol.
$\mathbf{G}+\mathbf{C}$ content. The $\mathrm{G}+\mathrm{C}$ content of the genomic DNA is $45 \% \mathrm{~mol} \%$ (as determined by the chemical method). Although this value is similar to values found for Desulfotomaculum species (Table 2), other properties justify placing this organism in a separate genus.

Type strain. Strain JW/IU-DC1 is the type strain of Desulfitobacterium dehalogenans; this strain has been deposited in the Deutsche Sammlung von Mikroorganismen as strain DSM 9161. The properties of this strain are the same as the properties described above for the species since it is the only strain that has been isolated so far.

\section{ACKNOWLEDGMENTS}

We are indebted to Dava Dalton for providing the enrichment culture, W. B. Whitman for help with the $\mathrm{G}+\mathrm{C}$ content determination, and $\mathrm{H}$. Trüper for correct derivation of the latinized names.

This work was supported by grant N00014-91-7-1874 from the Office of Naval Research.

\section{REFERENCES}

1. Abdollahi, H., and J. W. T. Wimpenny. 1990. Effects of oxygen on the growth of Desulfovibrio desulfuricans. J. Gen. Microbiol. 136: $1025-1030$.

2. Ausubel, F. M., et al. 1989. Current protocols in molecular biology, p. 2.4.1.-2.4.5. Wiley Interscience, New York.

3. Beuscher, N., F. Mayer, and G. Gottschalk. 1974. Citrate lyase from Rhodopseudomonas gelatinosa: purification, electron microscopy and subunit structure. Arch. Microbiol. 100:307-328.

4. Biggin, M. D., T. J. Gibson, and G. F. Hing. 1983. Buffer gradient gels and ${ }^{35} \mathrm{~S}$ label as an aid to rapid DNA sequence determination. Proc. Natl. Acad. Sci. USA 80:3963-3965.

5. Campbell, L. L., and J. R. Postgate. 1965. Classification of the spore-forming sulfate-reducing bacteria. Bacteriol. Rev. 29:359363.

6. Campbell, L. L., and R. Singleton, Jr. 1986. Genus IV. Desulfotomaculum, p. 1200-1202. In P. H. A. Sneath, N. S. Mair, M. E. Sharpe, and J. G. Holt (ed.), Bergey's manual of systematic bacteriology, vol. 2. Williams \& Wilkins, Baltimore.

7. Dalton, D. D. 1990. The enrichment and characterization of a microbial community derived from freshwater sediments which transforms 2,4-dichlorophenol under anaerobic conditions. M.S. thesis. University of Georgia, Athens.

8. Dannenberg, S., M. Kroder, W. Dilling, and H. Cypionka. 1992. Oxidation of $\mathrm{H}_{2}$, organic compounds and inorganic sulfur compounds coupled to reduction of $\mathrm{O}_{2}$ or nitrate by sulfate-reducing bacteria. Arch. Microbiol. 158:93-99.

9. De Soete, G. 1983. A least square algorithm for fitting additive trees to proximity data. Psychometrika 48:621-626.

10. DeWeerd, K. A., L. Mandelco, R. S. Tanner, C. R. Woese, and J. M. Suflita. 1991. Desulfomonile tiedjei gen. nov. and sp. nov., a novel anaerobic, dehalogenating, sulfate-reducing bacterium. Arch. Microbiol. 154:23-30.

11. Dilling, W., and H. Cypionka. 1990. Aerobic respiration in sulfatereducing bacteria. FEMS Microbiol. Lett. 71:123-128.

12. Doetsch, R. N. 1981. Determinative methods of light microscopy, p. 21-33. In P. Gerhardt, R. G. E. Murray, R. N. Costilow, E. W. Nester, W. A. Wood, N. R. Krieg, and G. B. Phillips (ed.), Manual of methods for general microbiology. American Society for Microbiology, Washington, D.C.

13. Frasca, J. M., and V. R. Parks. 1965. A routine technique for double-staining ultrathin sections using uranyl and lead salts. J. Cell Biol. 25:157-161.

14. Hanson, R. S., and J. A. Philips. 1981. Chemical composition, p. 328-364. In P. Gerhardt, R. G. E. Murray, R. N. Costilow, E. W. Nester, W. A. Wood, N. R. Krieg, and G. B. Phillips (ed.), Manual of methods for general microbiology. American Society for Microbiology, Washington, D.C.

15. Holt, J. G., N. R. Krieg, P. H. A. Sneath, J. T. Staley, and S. T. Williams (ed.). 1994. Bergey's manual of determinative bacteriology, p. 341. Williams \& Wilkins, Baltimore.

16. Jukes, T. H., and C. R. Cantor. 1969. Evolution of protein 
molecules, p. 21-132. In H. N. Munro (ed.), Mammalian protein metabolism. Academic Press, New York.

17. Kellenberger, E., A. Ryter, and J. Sechaud. 1958. Electron microscope study of DNA-containing plasma. II. Vegetative and mature phage DNA as compared with normal bacterial nucleosides in different physiological states. J. Biophys. Biochem. Cytol. 4:671678.

18. Klemps, R., H. Cypionka, F. Widdel, and N. Pfennig. 1985. Growth with hydrogen, and further physiological characteristics of Desulfotomaculum species. Arch. Microbiol. 143:203-208.

19. Kohring, G.-W., J. E. Rogers, and J. Wiegel. 1989. Anaerobic biodegradation of 2,4-dichlorophenol in freshwater lake sediments at different temperatures. Appl. Environ. Microbiol. 55:348-353.

20. Lane, D. J., B. Pace, G. J. Olsen, and D. A. Stahl. 1985. Rapid determination of $16 \mathrm{~S}$ ribosomal RNA sequences for phylogenetic analyses. Proc. Natl. Acad. Sci. USA 82:6955-6959.

21. Ljungdahl, L. G., and J. Wiegel. 1986. Anaerobic fermentations, p. 84-96. In A. L. Demain and N. A. Solomon (ed.), Manual of industrial microbiology and biotechnology. American Society for Microbiology, Washington, D.C.

22. Madsen, T., and J. Aamad. 1992. Isolation and characterization of an anaerobic chlorophenol-transforming bacterium. Appl. Environ. Microbiol. 58:2874-2878.

23. Marmur, J. 1961. A procedure for the isolation of deoxyribonucleic acid from microorganisms. J. Mol. Biol. 3:208-218.

24. Mesbah, M., U. Premachandran, and W. B. Whitman. 1989. Precise measurement of the $\mathrm{G}+\mathrm{C}$ content of deoxyribonucleic acid by high-performance liquid chromatography. Int. J. Syst. Bacteriol. 39:159-167.

25. Mohn, W. W., and J. M. Tiedje. 1992. Microbial reductive dehalogenation. Microbiol. Rev. 56:482-507.

26. Olsen, G. J., R. Overbeek, N. Larsen, T. L. Marsh, M. J. McCaughey, M. A. Maciukenas, W. M. Kuan, T. J. Macke, and C. R. Woese. 1992. The ribosomal database project. Nucleic Acids Res. 20(Suppl.):2199-2200.

27. Sanger, F., S. Nicklen, and A. R. Coulson. 1977. DNA sequencing with chain-terminating inhibitors. Proc. Natl. Acad. Sci. USA 74:5463-5467.
28. Shelton, D. R., and J. M. Tiedje. 1984. Isolation and characterization of bacteria in an anaerobic consortium that mineralizes 3-chlorobenzoic acid. Appl. Environ. Microbiol. 48:840-848.

29. Spurr, A. R. 1969. A low-viscosity epoxy resin embedding medium for electron microscopy. J. Ultrastruct. Res. 26:31-43.

30. Valentine, R. C., B. M. Shapiro, and E. R. Stadtman. 1968. Regulation of glutamine synthetase. XII. Electron microscopy of the enzyme from $E$. coli. Biochemistry 7:2143-2152.

31. Weisburg, W. G., J. G. Tully, D. L. Rose, J. P. Petzel, H. Oyaizu, D. Yang, L. Mandelco, J. Sechrest, T. G. Lawrence, J. van Etten, J. Maniloff, and C. R. Woese. 1989. A phylogenetic analysis of the mycoplasmas: basis for their classification. J. Bacteriol. 171:64556467.

32. Whitman, W. B., S. Sohn, D. S. Caras, and U. Premachandran. 1986. Isolation and characterization of 22 mesophilic methanococci. Syst. Appl. Microbiol. 7:235-240.

33. Widdel, F. 1992. The genus Desulfotomaculum, p. 1792-1799. In A. Balows, H. G. Trüper, M. Dworkin, W. Harder, and K.-H. Schleifer (ed.), The prokaryotes. Springer-Verlag, New York.

34. Wiegel, J. 1981. Distinction between the Gram reaction and the Gram type of bacteria. Int. J. Syst. Bacteriol. 31:88.

35. Wiegel, J., and L. G. Ljungdahl. 1979. Isolation from soil and properties of the extreme thermophile Clostridium thermohydrosulfuricum. J. Bacteriol. 139:800-810.

36. Wiegel, J., and L. Quandt. 1982. Determination of the Gram type using the reaction between polymyxin $\mathrm{B}$ and lipopolysaccharides of the outer cell wall of whole bacteria. J. Gen. Microbiol. 128:2261-2270.

37. Woese, C. R., R. Gutell, R. Gupta, and H. F. Noller. 1983. Detailed analysis of the higher-order structure of 16S-like ribosomal ribonucleic acids. Microbiol. Rev. 47:621-669.

38. Woese, C. R., M. Sogin, D. A. Stahl, B. J. Lewis, and L. Bonen. 1976. A comparison of the 16S ribosomal RNAs from mesophilic and thermophilic bacilli. J. Mol. Evol. 7:197-213.

39. Zhang, X., and J. Wiegel. 1990. Isolation and partial characterization of a Clostridium species transforming para-hydroxybenzoate and 3,4-dihydroxybenzoate and producing phenols as the final transformation products. Microb. Ecol. 20:103-121. 